\title{
Kanada - nowy kierunek emigracji Portugalczyków w II połowie XX wieku
}

W 2011 roku w Kanadzie mieszkało około 250 tysięcy osób czysto portugalskiego pochodzenia i prawie 180 tysięcy o korzeniach częściowo portugalskich. Pierwsza grupa emigrantów portugalskich dotarła do Kanady w 1953 roku, początkując tym samym niemal pół wieku dość licznego osadnictwa Portugalczyków w tym kraju. W ciągu kolejnych dekad Portugalczycy migrowali do Kanady w ponad 95\% w ramach sponsoringu rodzinnego, sąsiedzkiego czy udzielanego bliższym i dalszym znajomym. W efekcie kolejne grupy emigrantów portugalskich miały bardzo zbliżone do siebie charakterystyki: niemal zupełny brak wykształcenia, brak jakiegokolwiek przygotowania zawodowego, znajomość jedynie rodzimego języka. Diaspora portugalska w Kanadzie wywodzi się przede wszystkim z Azorów. Do dziś ponad 65\% portugalskiej grupy etnicznej to pierwsze lub kolejne pokolenia emigrantów z tych wysp. Portugalska grupa etniczna jest zaliczana przez badaczy do grup w trakcie przekształceń, choć niemal wszyscy przyznają, że są to procesy spóźnione w stosunku do innych zbiorowości etnicznych. Powodów takiego stanu jest wiele, wśród nich najważniejsze to: dominacja pierwszej generacji, która de facto nie posiada żadnego wykształcenia i dodatkowo nie ma nawyków edukacyjnych; socjalizacja większości emigrantów w czasach reżimu Salazara, skutkująca między innymi brakiem samodzielności; wewnętrzne rozbicie grupy jako efekt relacji wywiezionych z Europy, w tym poczucie marginalizowania pochodzącej z Azorów większości przez grupę z Portugalii kontynentalnej.

Słowa kluczowe: sponsoring, Azory, edukacja, Toronto, minha terra

\section{Canada - a new direction for Portuguese emigrants in the second half of the twentieth century}

In 2011, there were about 250,000 people of single Portuguese origin living in Canada and almost 180,000 who were partly Portuguese. The first group of Portuguese emigrants arrived in Canada in 1953, thus beginning almost a half-century period of quite large Portuguese

${ }^{1}$ Kontakt: marta.kijewska-trembecka@uj.edu.pl 
settlements in this country. Over the following decades, over 95\% of Portuguese have immigrated to Canada being sponsored by family, neighbors or other close or distant friends or relatives. As a result, the successive groups of Portuguese immigrants had very similar characteristics: they lacked proper education, professional qualifications, and had knowledge of their native language only. The Portuguese diaspora in Canada originates primarily from the Azores. To date, over $65 \%$ of the Portuguese ethnic group is represented by the first or successive generations of emigrants from these islands. The Portuguese ethnic group is classified by researchers as a group undergoing a transformation, although almost everyone admits that this is a relatively late process when compared to other ethnic communities. There are many reasons for this, among them the most important are: the dominance of the first generation, which in fact lacks education and, additionally, has no education habits; the socialization during the Salazar regime, which was the experience of most of Portuguese emigrants, resulting in, inter alia, a lack of independence; divisions within the group resulting from the relations exported from Europe, including the sense of marginalization of the Azoreans by a group from mainland Portugal.

Keywords: sponsoring, Azores, education, Toronto, minha terra

\section{Wprowadzenie}

Z początkiem XXI wieku minęło pięćdziesiąt lat od przybycia do Kanady pierwszych grup portugalskich imigrantów. W 2011 roku w kraju tym mieszkało około 250 tysięcy osób czysto portugalskiego pochodzenia i prawie 180 tysięcy o korzeniach częściowo portugalskich ${ }^{2}$. Portugalska grupa etniczna jest zaliczana przez badaczy do grup w trakcie przekształceń, choć niemal wszyscy przyznają, że są to procesy spóźnione w stosunku do innych zbiorowości etnicznych i dodatkowo wolniej przebiegające. Tekst analizuje przyczyny takiego stanu rzeczy, wśród nich najważniejsze to: dominacja pierwszej generacji, która de facto nie posiada żadnego wykształcenia i dodatkowo nie ma nawyków edukacyjnych; socjalizacja większości emigrantów w czasach reżimu Salazara, skutkująca między innymi brakiem samodzielności; wewnętrzne rozbicie grupy jako efekt relacji wywiezionych z Europy, w tym poczucie marginalizowania większości pochodzącej z Azorów (około 65\% portugalskiej grupy etnicznej) przez grupę z Portugalii kontynentalnej ${ }^{3}$.

W polskich badaniach etnicznych rzadko pojawia się problematyka współczesnej emigracji portugalskiej, w szczególności jej kanadyjskiego nurtu. Tekst ten, będąc przeglądem literatury przedmiotu, ma choć po części wypełnić tą lukę.

W latach 50. XX wieku Portugalia, a głównie reżim Salazara, świętowali pięćsetlecie obecności Luzytan u wschodnich wybrzeży dzisiejszej Kanady ${ }^{4}$. Wielowieko-

${ }^{2}$ http://www12.statcan.gc.ca/nhs-enm/2011 (dostęp: 2018-02-15).

3 Armando Oliveira M., 2009, Azorean Diaspora and Cultural Retention in Montreal and Toronto, w: Teixeira C., da Rosa V., 2009, The Portuguese in Canada. Diasporic Challenges and Adjustment, Toronto: University of Toronto Press, s. 91-108.

${ }^{4}$ Kijewska-Trembecka, M., 2018, Od wielkich odkryć po White Fleet. Diaspora portugalska w świecie i przedemigracyjne kontakty Portugalczyków z Kanadą, „Studia Migracyjne - Przegląd Polonijny" nr 1, s. 241-257. 
we kontakty portugalskich żeglarzy i rybaków z mieszkańcami Nowej Fundlandii, a w szczególności półwyspu Avalon i miasta St. John’s, nigdy nie przełożyły się na osiedlanie się Portugalczyków na tych terenach. Można było oczywiście ich znaleźć wśród mieszkańców tej wyspy, a nawet przemierzających Zatokę i rzekę św. Wawrzyńca, aby pozostać w Nowej Francji czy później w Kanadzie Brytyjskiej. To jednak, na przestrzeni wieków, bardzo nieliczna grupa.

Prawdopodobnie pierwszym Portugalczykiem, który mieszkał przez pewien czas na terenach dzisiejszej Kanady, był Mateus da Costa, który towarzyszył Samuelowi de Champlain ${ }^{5} \mathrm{w}$ jego podróży do Acadii w 1606 roku. Da Costa był tłumaczem w kontaktach z Indianami, co oznaczałoby, że przebywał w Nowym Świecie dłużej i miał czas nauczyć się języków natives. Co ciekawe, da Costa był wolnym czarnym człowiekiem, prawdopodobnie opuścił którąś z portugalskich wypraw końca XVI wieku'. Kilka dekad później w pobliżu osady Quebec w Nowej Francji osiedlił się urodzony w Lizbonie Pedro da Silva, zwany Portugalczykiem. W 1677 roku w Quebecu ożenił się z Jeanne Greslon i mieli piętnaścioro dzieci. Był pierwszym oficjalnym nowofrancuskim pocztowcem (listonoszem?), który dostarczał przesyłki między Quebekiem a Montrealem, przede wszystkim od i do gubernatora Nowej Francji ${ }^{7}$. Następnym znanym portugalskim osadnikiem w Kanadzie jest urodzony w Bradze Martin Pire-Henne, także zwany Portugalczykiem. W 1674 roku ożenił się w Quebecu z Francoise du Faye i miał siedmioro dzieci. João Rodrigues to kolejny Portugalczyk urodzony w Lizbonie a mieszkający w Quebecu. Dochował się oryginalny dokument mówiący o zawartym w Quebecu w dniu 13 października 1671 roku ślubie J. Rodriguesa z Anne LeRoy ${ }^{8}$.

W XVIII wieku do Montrealu docierali portugalscy Żydzi, nierzadko via Bordeux lub Nowy Jork. W latach 60. tego wieku była ich tu niewielka grupa, około 15 osób i to oni w 1768 roku ufundowali pierwszą w Montrealu świątynię niekatolicką - synagogę Shearith Israel, znaną pod nazwą the Spanish and Portuguese Synagogue. Swoją nazwę wzięła od synagogi nowojorskiej, była to świątynia żydów sefardyjskich. W roku 2018 przypada dwieście pięćdziesiąt lat jej istnienia9 ${ }^{9}$

${ }^{5}$ Samuel de Champlain ( 1574-1635) francuski podróżnik i kartograf, przepłynął rzekę św. Wawrzyńca, a odkryte ziemie uznał za kolonie francuskie. Był pierwszym gubernatorem Nowej Francji (1608-1763) wielce zasłużonym dla jej rozwoju. Zwany jest ojcem narodu quebeckiego, a trzy tomy jego Les Voyages są bezcennym źródłem informacji o początkach Kanady.

${ }^{6}$ Boyko, John, 1998, Last Steps to Freedom: The Evoluation of Canadian Racism, Toronto: J. Gordon Shillingford, s. 158.

${ }^{7}$ W 2003 roku, w 50. rocznicę zapoczątkowania emigracji Portugalczyków do Kanady, kanadyjska poczta wyemitowała znaczek upamiętniający Pedro da Silvę. https://www.pier21.ca/research/ pier-21/the-portuguese-in-canada (dostęp: 2018-03-26).

${ }^{8}$ Alpalhao, Antonio J., da Rosa, Victor M.P., 1979, Les Portugais du Québec. Elements d'analyse socio-culturelle Ottawa: Editions de l'Universite d'Ottawa, s. 60-64; Higgs, David, 1990, Portuguese Migration in Global Perspective, Toronto: The Multicultural History Society of Ontario, s. 203, Appendix.

${ }^{9} \mathrm{http}: / /$ imjm.ca/location/1788, Anderson, G.M., Higgs, D., 1976, A Future to Inherit. The Portuguese Communities of Canada, Toronto: McClelland and Stewart, s. 19. Żydzi zostali oficjalnie 
Jak podaje Grace Anderson w 1871 roku, według danych pierwszego kanadyjskiego spisu ludności z tegoż roku, w Dominium Kanady mieszkało 829 osób pochodzenia portugalskiego i hiszpańskiego, wówczas obie grupy liczono razem ${ }^{10}$.

W 1940 roku portugalski dziennikarz Jorge Simoes towarzyszył Białej Flocie w rejsie do St. John's. W porcie i okolicach próbował odnaleźć Portugalczyków, którzy osiedli na Nowej Fundlandii. Po kilku tygodniach poszukiwań znalazł jedynie trzech mężczyzn portugalskiego pochodzenia. Wszyscy trzej, w różnym czasie, zeszli ze statków i nie wrócili do kraju ${ }^{11}$.

Tuż po II wojnie światowej Portugalczycy także nie wyjeżdżali do Kanady. Wówczas emigracja $z$ tego kraju była kontrolowana przez reżim Salazara, a Kanada nie znajdowała się na głównych szlakach wyjazdowych z Portugalii. Z drugiej strony, kanadyjskie przepisy imigracyjne praktycznie wykluczały przyjmowanie Portugalczyków, a oni woleli Brazylię, Wenezuelę oraz kraje europejskie, a ci z Azorów przede wszystkim USA ${ }^{12}$. Statystyki kanadyjskie pokazują, że w latach 1946-1950 do Kanady przyjechało 267 imigrantów z Portugalii, a wraz z tymi, którzy osiedli tu wcześniej, portugalska grupa etniczna w Kanadzie w 1951 roku liczyła 1028 osób ${ }^{13}$.

\section{Emigracja II połowy $\mathrm{XX}$ wieku}

Pierwsza grupa emigrantów portugalskich dotarła do Kanady w 1953 roku, początkując tym samym niemal pół wieku dość licznego osadnictwa Portugalczyków w tym kraju. Lata 50. XX wieku to jeszcze okres obowiązywania kanadyjskich przepisów imigracyjnych opartych na zasadach dyskryminujących przybyszy z Półwyspu Iberyjskiego. Według tych przepisów, które oficjalnie obowiązywały do 1967 roku, do Kanady mogli emigrować jedynie biali mieszkańcy Europy i Amerykanie. Potencjalni imigranci byli podzieleni na trzy grupy: pożądani, preferowani

wykluczeni z możliwości osiedlania się we francuskiej kolonii - Nowej Francji (1608-1763) dwukrotnie - w 1615 i 1627 roku. Kijewska-Trembecka, M., 2008, Montrealscy Żydzi: od dyskryminacji do sukcesu, w: Szmeja, M., 2008, red., Etniczność - o przemianach społeczeństw narodowych, Kraków: Nomos, s. 102. W koloniach angielskich the Plantation Act, 1740 zezwalał Żydom, a nawet ich zapraszał, do osadnictwa tamże. Godfrey, Sheldon, J., Godfrey, Judith C., 1995, Search of the Land. The Jews and the Growth of Equality in British Colonial America, 1740-1867, Montreal: McGill-Queen's University Press, s. 52-62.

${ }_{10}$ Anderson, Higgs, 1976, s. 19. Grace Anderson, (1923-1989) jest pionierką badań nad portugalską grupą etniczną w Kanadzie i uznawana jest za największy autorytet w tej kwestii.

11 Ibidem s. 13.

${ }_{12}$ Więcej: Kijewska-Trembecka, 2018, s. 244-246; Walaszek, A., 2013, Dwie europejskie peryferie: porównanie migracji portugalskich i polskich od XVI wieku do wielkiej wojny, „Studia Migracyjne Przegląd Polonijny" nr 2, s. 34 .

${ }_{13}$ Canada. Bureau of Statistics, Census of Canada 1951. Ethnic Groups (www. statcan.ca/historical_profiles, dostęp: 2018-02-26). 
i niepreferowani, ale przyjmowani. W żadnej z tych kategorii nie znaleźli się Portugalczycy, gdyż długo nie byli uznawani za białych, a zaliczani do kategorii pośredniej, między białą a kolorową, czasem używano określenia rasa oliwkowa oil-skinned. Jednak życie płynęło własnym rytmem i do Kanady trafiali przybysze także z krajów nieuwzględnionych w oficjalnych przepisach. Docierali tam głownie w ramach wprowadzonych w latach 50 . XX wieku możliwości różnych form sponsoringu i później łączenia rodzin, z tego korzystali Portugalczycy. Imigranci przybywali do Kanady też różnymi nielegalnymi sposobami, z tego Portugalczycy nie korzystali. Dopiero zmiana przepisów imigracyjnych na tzw. system punktowy, który wszedł w życie w 1967 roku, zakończyła dyskryminację kanadyjskich imigrantów bazującą na rasie i kraju pochodzenia ${ }^{14}$.

W wyniku porozumienia rządu Salazara z Ottawą portugalscy imigranci pojawili się w Kanadzie wiosną 1953 roku. Stało się tak, gdyż Kanadyjczycy poszukiwali imigrantów, niewykwalifikowanych robotników, przede wszystkim do pracy na farmach, w gospodarce leśnej i przy rozbudowie sieci kolejowej. Imigrantami chcieli zapełnić lukę, jaka powstała na kanadyjskim rynku pracy, gdy na przełomie lat 40./50. XX wieku nastąpił znaczny exodus ludności ze wsi do miast i miasteczek. Wydawało się, że Portugalczycy, pochodzący niemal wyłącznie ze wsi, będą odpowiednimi w tej sytuacji ${ }^{15}$. Przybyło wówczas ponad 500 osób, niemal wyłącznie żonaci mężczyźni, w większości pochodzili z Azorów (głównie z wyspy Sao Miguel) - ponad 60\%, z północno-zachodniej Portugalii - około 37\% i z Madery ${ }^{16}$. Do pracy rozjechali się po całej Kanadzie i, niezwiązani obowiązkami rodzinnymi, często zmieniali miejsce pobytu w poszukiwaniu lepszego zarobku. Nie znali języka, w większości nie mieli pojęcia o kanadyjskich odległościach i klimacie, żadne prawa pracownicze ich nie obejmowały. Wszystko zależało od gospodarza. Praca na farmach była nie dość, że bardzo ciężka, często w warunkach klimatycznych, których imigranci $\mathrm{z}$ atlantyckich wysp w ogóle nie znali, to mocno doskwierała im samotność, brak nie tylko rodziny, ale także krajan, z którymi mogliby choćby porozmawiać w swoim języku, innego nie znali. Dlatego wykorzystywali każdą sposobność, żeby dołączyć do innych rodaków, a praca wśród swoich możliwa

${ }^{14}$ Kijewska-Trembecka M., 1994, Kanada - naród czy wspólnota polityczna. Analiza kanadyjskich procesów integracyjnych, Kraków: WUJ, s. 33-34. Przejmującą analizę rasistowskiego podejścia anglosaskiego świata wobec Portugalczyków przedstawił Robert F. Harney w artykule „Portygees and Other Caucasians". Portuguese migrants and the racialism of the English-speaking world, in: Higgs, D., ed., 1990, Portuguese Migration in Global Perspective, Toronto: The Multicultural History Society of Ontario, s. 113-135.

${ }^{15}$ Marques, Domingos, Medeiros João, 1980, Portuguese Immigrants. 25 Years in Canada, Toronto: Marquis Printers, s. 26-27.

${ }^{16}$ Rocha-Trindade M., 2009, The Portuguese Diaspora, w: Teixeira C., da Rosa V., 2009, s. 25; Anderson, Higgs, 1976, s. 64. 
była jedynie w mieście ${ }^{17}$. Warunki pracy i życia, z jakimi przyszło się tej pierwszej grupie zmagać w Kanadzie, spowodowały, że imigranci z połowy lat 50. XX wieku byli najbardziej mobilną grupą wśród wszystkich Portugalczyków, którzy przybyli do Kanady w ciągu kolejnych dekad XX wieku ${ }^{18}$.

Do pierwszej fali imigrantów szybko dołączali następni, także najczęściej samotni mężczyźni. Kobiety i dzieci przyjeżdżały najwcześniej po czterech, pięciu a nierzadko nawet po dziesięciu latach. W ciągu kolejnych dekad Portugalczycy migrowali do Kanady w ponad $95 \% \mathrm{w}$ ramach sponsoringu rodzinnego, sąsiedzkiego czy udzielanego bliższym i dalszym znajomym. Tylko niecałe $5 \%$ stanowiły indywidualne aplikacje ${ }^{19}$. Wszyscy jechali już niemal wyłącznie do miast, głównie do Toronto i Montrealu, do tworzących się tam, coraz liczniejszych skupisk portugalskich przybyszów.

Łańcuchowa emigracja z Azorów, kontynentalnej Portugalii czy Madery do Kanady jako efekt przede wszystkim powiązań rodzinnych, lokalnych, a nie niezależnych wyborów dokonywanych przez migrujących, była konsekwencją nie tylko mocnych związków Portugalczyków z minha terra, ojczyzną prywatną, jak określił to Ossowski ${ }^{20}$. Powodem takich procesów było także to, że kolejne grupy emigrantów udających się do Kanady miały bardzo zbliżone do siebie charakterystyki: niemal zupełny brak wykształcenia, brak jakiegokolwiek przygotowania zawodowego, znajomość jedynie rodzimego języka, co nierzadko oznaczało niekoniecznie portugalski w wersji oficjalnej a bardziej odmianę regionalną, na przykład używaną na wyspie, $\mathrm{z}$ której pochodzili ${ }^{21}$. W konsekwencji emigranci z kolejnych lat zamieszkiwali w Kanadzie obok tych, którzy ich tam sprowadzili. Sponsorujący szukali pracy, najczęściej tam, gdzie sami pracowali, zapewniali lokum, zwykle u siebie lub sąsiada, wprowadzali w nowe życie, dawali poczucie bezpieczeństwa w nieznanym otoczeniu i możliwość przynależności do wspólnoty. Lojalność wobec rodziny, domu, wioski, regionu determinowała to, gdzie w Kanadzie pierwsze pokolenie migrantów mieszkało, pracowało, robiło zakupy, chodziło do kościoła i spędzało wolny czas. Bardzo szybko w Toronto, w mniejszym stopniu w Montrealu, stworzyły się zwarte portugalskie sąsiedztwa, Little Portugals ${ }^{22}$.

W ciągu kolejnych dziesięcioleci, do końca lat 80 . XX w., do Kanady emigrowało coraz więcej Portugalczyków, nie są to wprawdzie wielkości porównywalne z ich

17 Marques, Medeiros, 1980, s. 30-32.

${ }^{18}$ Higgs, D., 1982, The Portuguese in Canada, Ottawa: The Canadian Historical Association, s. 8.

19 Ibidem, s. 7.

20 Ossowski, St., 1984, Analiza socjologiczna pojęcia ojczyzny, w: O ojczyźnie i narodzie, Warszawa: PWN, s. 21-27.

${ }^{21}$ Według kanadyjskich badań w latach 60. XX wieku średni poziom edukacji wśród Portugalczyków mieszkających w Toronto i Montrealu wynosił: 3,7 lat dla mężczyzn i 2,8 lat dla kobiet. Burnet, J., Palmer, H., 1988, Coming Canadians. An Introduction to a History of Canada's Peoples, Toronto: McClelland and Steward, s. 116.

${ }^{22}$ Higgs, 1982, s. 7. Zdarzyło się, że jeden z „pionierów” sprowadził, w ciągu 25 lat pobytu w Kanadzie, ponad 200 osób ze swojej rodziny i sąsiedztwa. Ibidem, s. 6. 
wyjazdami na przykład do Brazylii czy Francji, ale migracje do Kanady wyraźnie nabrały tempa.

Według oficjalnych kanadyjskich statystyk w 2006 roku w Kanadzie mieszkało 6,2 mln imigrantów, osób urodzonych poza tym krajem, z czego 150, 3 tys. urodziło się w Portugalii. Wśród nich najwięcej było osób, które przyjechały do Kanady przed 1991 rokiem - 137 tys.; w kolejnych latach 1991-95 przyjechało 7,8 tys. osób; w okresie 1996-2000 - 2,7 tys. ${ }^{23}$ Wyliczenia podane przez Teixeira, mówią, że w ciągu ponad pięćdziesięciu lat do Kanady dotarło około 217 tys. emigrantów z Portugalii, czyli ponad 60 tys. więcej niż mieszkało ich w Kanadzie w 2007 roku. Według jego danych w latach 1950-59 przyjechało 17,1 tys. osób; 1960-69 - 59,7 tys.; w 1970-79 aż 80 tys.; w 1980-89 - 38,2 tys.; w 1990-99 - 19,2 tys. i w latach 2000-2007 - 2,9 tys. Między rokiem 2008 a 2016 w Kanadzie osiedliło się około 6 tys. Portugalczyków ${ }^{24}$.

Emigracja z Portugalii w latach 60. i 70. XX była bardzo liczna, jedynie niewielka jej część dotarła do Kanady. Portugalczycy, w szczególności mieszkańcy wysp, szukali lepszego życia, bo wieloletnie rządy ekipy Salazara doprowadziły gospodarkę kraju do strukturalnego zacofania a ludzi po prostu do biedy. Sam Salazar popierał wyjazdy jako jeden ze sposobów rozładowania napięcia w kraju. Dodatkowo po upadku reżimu, w połowie lat 70. XX w. do kraju wróciło ponad pół miliona osób z koloniii ${ }^{25}$, które właśnie uzyskały niezależność od Lizbony. Dla Portugalii było to wielkie wyzwanie, $\mathrm{z}$ którym nie bardzo mogła sobie poradzić. Pewna ich część od razu pojechała dalej. Do Kanady trafiło jedynie około 3 tys. powracających $\mathrm{z}$ kolonii ${ }^{26}$. Od lat 80 . XX w. wyjazdy do Kanady wyraźnie wyhamowały, nie znaczy to, że Portugalczycy przestali emigrować, zmienili tylko kierunek wyjazdów. Od 1986 roku Portugalia należy do Unii Europejskiej i w ciągu ostatnich trzech dekad mieszkańcy tego kraju wyjeżdżają bliżej, do krajów unijnych.

Jak wspomniano wyżej diaspora portugalska w Kanadzie wywodzi się przede wszystkim z Azorów. Od początku osadnictwa w Kanadzie po dziś, ponad 65\% portugalskiej grupy etnicznej to pierwsze lub kolejne pokolenia emigrantów z tych wysp. Jedną z najmocniejszych ich charakterystyk jest to, że niemal w ogóle nie biorą pod uwagę powrotu do kraju, na Azory. Z Kanadą wiążą przyszłość swoją

23 Dla porównania wielkości - w latach 2001-2006 Kanada przyjęła ogółem 1,1 mln imigrantów. http://www.statcan.gc.ca/tables-tableaux/sum-som/101/cst01/demo24a-eng.htm (dostęp: 2018-02-15).

${ }^{24}$ Teixeira, da Rosa, 2009, s. 6, tab. 1.1; http://observatorioemigracao.pt/Canada (dostęp: 201802-25).

${ }^{25}$ Do dziś w Portugalii na określenie osób, które wróciły z kolonii, używa się słowa retornados, „ci, którzy wrócili do domu”. Maciel, C., 2013, Portuguese retornados from the colonies in Portugal since the 1970s, in: Blade, K.J., Emmer, P.C., Lucassen, L., Oltmer, J., The Encyclopedia of Migration and Minorities in Europe. From the $17^{\text {th }}$ Century to the Present, Cambridge: Cambridge University Press, s. 623-625.

${ }^{26}$ Rocha-Trindade, 2009, s. 30-32; Marques, Medeiros, 1980, s. 21. 
i swoich dzieci. Mniej więcej jedna czwarta przybyszów z innych części Portugalii, w szczególności z kontynentu, planuje, wcześniej czy później, powrót ${ }^{27}$.

Według statystyk z 2006 roku w Kanadzie mieszkało 262,2 tys. osób deklarujących czysto portugalskie pochodzenie i niemal 150 tys. (148,6 tys.) osób w kategorii pochodzenie wieloetniczne, także portugalskie. W tym samym roku wśród nich aż 230 tysięcy zadeklarowało, że ich językiem ojczystym jest portugalski. Najnowsze ogólnodostępne dane statystyczne z kanadyjskiego spisu z roku 2011 mówią, że w Kanadzie w tymże roku mieszkało 250,3 tys. osób o korzeniach wyłącznie portugalskich i prawie 180 tys. pochodzenia wieloetnicznego, w tym portugalskiego. Wśród osób należących do pierwszej kategorii, 140 tys., 56\% urodziło się w Portugalii, nadal więc w tej grupie przeważa pokolenie imigrantów ${ }^{28}$.

Tabela 1.

Portugalska grupa etniczna w Kanadzie, wybrane (najliczniej zamieszkałe) prowincje i miasta, rok 2011 (dane w tys.)

\begin{tabular}{|c|c|c|}
\hline & $\begin{array}{c}\text { Pochodzenie wyłącznie } \\
\text { portugalskie }\end{array}$ & $\begin{array}{l}\text { Pochodzenie między } \\
\text { innymi portugalskie }\end{array}$ \\
\hline \multicolumn{3}{|c|}{ Prowincje } \\
\hline Ontario & 184,2 & 110,7 \\
\hline Quebec & 34,5 & 24,8 \\
\hline Kolumbia Brytyjska & 15,4 & 21,1 \\
\hline Manitoba & 7,4 & 5,3 \\
\hline \multicolumn{3}{|c|}{ Miasta } \\
\hline Toronto & 128,5 & 68,4 \\
\hline Montreal & 29,5 & 18,8 \\
\hline Vancouver & 9,4 & 12,3 \\
\hline Ottawa-Gatineau & 6,3 & 5,9 \\
\hline Victoria & 1,3 & 2,1 \\
\hline Quebec Ville & 0,79 & 1,3 \\
\hline \multicolumn{3}{|c|}{ ogółem w Kanadzie } \\
\hline & 250,3 & 179,5 \\
\hline
\end{tabular}

Źródło: http://www12.statcan.gc.ca/nhs-enm/2011 (dostęp: 2018-02-15)

27 Higgs, 1982, s.14.

${ }^{28}$ http://www12.statcan.gc.ca/nhs-enm/2006 (dostęp: 2018-02-17); http://www12.statcan.gc.ca/ nhs-enm/2011 (dostęp: 2018-02-15); w języku polskim więcej; Kijewska-Trembecka, M., red., 2013, Kanada na przełomie XX i XXI wieku. Polityka, społeczeństwo, edukacja, Kraków: Księgarnia Akademicka, s. 174. 
Portugalczycy, jak większość kanadyjskich imigrantów II połowy XX wieku, zamieszkali głównie w Ontario. Dane ze spisu z 1981 roku mówią, że w Kanadzie mieszkało wówczas 188 tys. osób pochodzenia portugalskiego, z czego 129 tys. w Ontario, a w samym Toronto niemal 60 tys. osób. W tym samym czasie w Quebec mieszkało ich 27,3 tys., w Kolumbii Brytyjskiej - 16 tys., w Manitobie - 7,8 tys., w Albercie - 6 tys., a w Nowej Fundlandii - 245 osób $^{29}$.

Trzy dekady później, w 2011 roku, dane spisowe dotyczące rozmieszczenia portugalskiej grupy w Kanadzie były następujące (tabela 1).

Dane z 2011 pokazują, że osoby pochodzenia częściowo portugalskiego nierzadko przenoszą się z miast, gdzie znajdują się tradycyjne portugalskie sąsiedztwa w miejsca bardziej zróżnicowane etnicznie. Niezbyt często czynią to osoby o czysto portugalskim pochodzeniu. Wielkości te mówią także o tym, że portugalska grupa etniczna mieszkająca poza Toronto, czyli poza największym, tradycyjnym portugalskim sąsiedztwem, jest dość otwarta na egzogamię

\section{Portugalska grupa etniczna w Kanadzie - kilka charakterystyk}

Wartością, która dawała portugalskim imigrantom pewność, że w nowych warunkach człowiek nie zostanie pozostawiony samemu sobie, była cunha, czyli wzajemne poczucie lojalności, więzi i odpowiedzialności za osoby, z którymi jest się w jakiś sposób związanym. Cunha to także pewien rodzaj instytucji, jakby patronatu, to opiekun, który udzieli wsparcia, pomocy w razie potrzeby. To mocny element spajający wspólnotę przywieziony z minha terra. Taką wspólnotowość zdecydowanie popierał reżim Salazara, który kreował państwo, na „oficjalnego” cunha, mając na celu także zwalczenie wszelkiego indywidualizmu w społeczeństwie Estado Novo. Żyjący przez dziesięciolecia w takim kraju Portugalczycy również na emigracji nierzadko poszukiwali pomocy w rozwiązaniu prostych, codziennych problemów, jak np. opłata rachunków, odpowiedź na pismo urzędowe, w portugalskich konsulatach. Urzędnicy tych placówek byli uznawani właśnie za oficjalnych cunhas $^{31}$.

Jednak ta wewnętrzna solidarność grupy portugalskiej miała i ma także swoje ograniczenia, sprowadza się niemal wyłącznie do relacji z bliskimi, do więzów w ramach społeczności pochodzącej z tego samego regionu. Nie ma w Kanadzie ogólnoportugalskiej solidarności ponad podziałami regionalnymi wywiezionymi z kraju. Szczególnie mocno podkreślają to przybysze z Azorów, czyli prawie dwie

29 Tu ważna uwaga, w spisie z 1981 roku nie było rozdziału na single ethnic origin i multiple origin. Pochodzenie etniczne znaczyło pochodzenie ze strony ojca. Canada. Bureau of Statistics, Census of Canada 1981. Ethnic Groups (www. statcan.ca/historical_profiles).

${ }^{30}$ Burnet, Palmer, 1988, s. 98.

31 Higgs, 1982, s. 10. 
trzecie portugalskiej diaspory w Kanadzie. Mówią, że tak jak w kraju mieszańcy Portugalii kontynentalnej uważali ich za gorszą część społeczeństwa i zawsze dawali tego dowody, a reżim Salazara w szczególności zaniedbywał wyspy i marginalizował ich mieszkańców, tak i tu w Kanadzie emigranci są mocno podzieleni a Azorczycy czują się znowu wykluczani. Relacje z kraju zostały przeniesione za ocean ${ }^{32}$.

Portugalczycy nie tylko mieszkali blisko siebie na emigracji, ale niemal zawsze znajdowali również zatrudnienie tam, gdzie pracowali ich krajani, zazwyczaj także $\mathrm{z}$ ich polecenia. Ich domeną była praca w budownictwie, w szczególności wielkoobiektowym, rozbudowie dróg i kolei, prace remontowe i porządkowe, $\mathrm{w}$ fabrykach przy taśmach i innych prostych, fizycznych czynnościach. Często byli tzw. gospodarzami budynków, gdzie dbali nie tylko o porządek, ale i wykonywali drobne, bieżące naprawy. W miarę upływu czasu, ci którzy potrafili porozumieć się po angielsku, pracowali jako kierowcy ciężarówek czy autobusów. Pracowały także portugalskie kobiety, choć w rodzinnym kraju ich praca poza domem była rzadkością. W Toronto, mniej w Montrealu, stworzyły sieci portugalskich sprzątaczek, czasem zwane "gangami”. Sprzątały instytucje publiczne, najczęściej wielkie biurowce i supermarkety, zajmowały się tzw. lekkim sprzątaniem. Pracowały wieczorami i nocami, gdy ich mężowie wracali do domów i mogli zająć się dziećmi. Tak jak oni nie miały żadnych kwalifikacji zawodowych, a do tego często były po prostu niepiśmienne. Praca wśród własnej grupy etnicznej była więc dla nich najczęściej jedyną możliwą formą zarobkowania. Praca kobiet była ważna także dlatego, że w okresie zimowym mężczyźni nierzadko nie mieli zatrudnienia i wtedy tylko one utrzymywały rodziny ${ }^{33}$. Dodatkowo, jak większość emigrantów z biednych regionów, Portugalczycy czuli się w obowiązku pomagać bliższej i dalszej rodzinie, która została w kraju, nawet gdy najbliżsi byli już razem z nimi na emigracji. Część wysyłanych pieniędzy przeznaczano także na budowę lub kupno domu przez tych, którzy planowali powrót. W 1968 roku z Kanady do Portugalii wysłano niemal 8 milionów escudos, według obecnych przeliczeń byłoby to około 40 tysięcy euro, ale oczywiście trzeba uwzględnić różnice (w czasie) siły nabywczej pieniądza. W 1979 roku było to już 120 milionów escudos (około 600 tys. euro) ${ }^{34}$. Zjawisko to było charakterystyczne nie tylko dla pierwszych dekad emigracji do Kanady, istnieje także w XXI wieku. Dane opublikowane przez Observatorio da Emigracao Instituto Universitário de Lisboa, ISCTE (University Institute of Lisbon) mówią, że w latach 2000-2017

32 Armando Oliveira, 2009, s. 103-104.

${ }^{33}$ Przejmujący opis warunków, ale i hartu ducha portugalskich kobiet pracujących w Toronto znaleźć można w tekście Susan M. Miranda Portuguese Women's Activism in Toronto’s Building Cleaning Industry, in: Teixeira, da Rosa, 2009, s. 109-135.

${ }_{34}$ Alpalhao, João, A., da Rosa, Victor, 1980, A Minority in a Changing Society. The Portuguese Communities of Quebec, Ottawa: University of Ottawa Press, s. 205. Portugalska waluta escudo została w 2002 roku zastąpiona euro, ale co ciekawe nadal w wielu miejscach, nie tylko w Lizbonie, można płacić escudos. 1 stycznia 2002 roku wymieniano 200,482 escudos za 1 euro. 
diaspora portugalska w Kanadzie przesłała do kraju ponad 1 mld 115 mln euro. Jednak wielkości transferów z roku na rok zdecydowanie maleją, w 2000 roku było to ponad $145 \mathrm{mln}$ euro, a w 2017 tylko niecałe $26 \mathrm{mln}^{35}$.

Ważnym obszarem, który dawał Portugalczykom w Kanadzie środki do życia były małe, rodzinne biznesy zakładane najczęściej w portugalskim sąsiedztwie i działające przede wszystkim na jego rzecz. Wraz z przybywaniem kolejnych grup imigrantów powstawały niewielkie sklepy, najczęściej spożywcze z rybami, oliwą, owocami i winem, kawiarnie, gdzie można było, zgodnie z portugalską tradycją, wyjść z rodzinną na kawę, małe restauracyjki, zakłady fryzjerskie czy krawieckie. I choć nie mieli żadnego doświadczenia w prowadzeniu jakiegokolwiek biznesu, to dzięki pomocy rodziny i znajomych mogli przetrwać różne kryzysy czyhające na nich na wolnym rynku ${ }^{36}$.

Istotną rolę w życiu portugalskiej diaspory w Kanadzie, w szczególności pierwszego pokolenia, odegrał Kościół katolicki. Kościół skupiał Portugalczyków wokół świąt popularnych portugalskich świętych, ale przede wszystkim wokół kultu Matki Boskiej z Fatimy. Niemal wszyscy imigranci wywodzili się z tradycyjnie religijnych regionów, a żyjąc w Estado Novo mieli do czynienia z instytucjami katolickimi w każdym obszarze swojego życia. W Toronto msze święte po portugalsku odprawiane były od 1956 roku, a w Montrealu od 1960 roku $^{37}$.

Jest rzeczą niemal naturalną, że taka grupa jak portugalska bardzo szybko na emigracji wytworzyła własną kompletność instytucjonalną ${ }^{38}$, która pozwoliła członkom grupy na funkcjonowanie w poczuciu pewnego bezpieczeństwa społecznego. Bardzo zbliżony status zawodowy, bliskość zamieszkania i najczęściej zatrudnienia, wspólnota religijna i drobne biznesy etniczne, brak znajomości języka angielskiego lub francuskiego i minimalny poziom edukacji, wszystko to powodowało, że szybko powstawały etniczne instytucje i organizacje, w ramach których grupa zaspokajała swe potrzeby tak prywatne, jak i wspólnotowe. Higgs pisze, że „paradoksalnie, mieszkanie w dużym mieście wzmagało nostalgię za Portugalią, a szczególnie małym miasteczkiem, minha terra, za ciepłem, słońcem i morzem; za bliskością relacji z ludźmi i za językiem, który rozumieli. Przeciwstawiali wrażliwość i delikatność portugalskich kobiet brakowi <skromności> kobiet w Kanadzie"39.

Pierwsze portugalskie organizacje pojawiły się już w 1956 roku: w Montrealu Portuguese Association of Canada; w Toronto - The First Portuguese Canadian Cultural Centre i bardzo szybko powstały następne, bardzo różnorodne w formach swojego działania, ale co bardzo charakterystyczne dla tej grupy, mające zasięg

${ }^{35} \mathrm{http}: / /$ observatorioemigracao.pt/Canada (dostęp: 2018-02-25).

36 Higgs, 1982, s. 9.

37 Ibidem, s. 10.

${ }^{38}$ Breton, R., 1964, Institutional Completeness of Ethnic Communities and the Personal Relations of Immigrants, „American Journal of Sociology”, vol. LXX, september, no. 2, s.193-205.

${ }^{39}$ Higgs, 1982, s. 11. 
przede wszystkim lokalny a nie ogólnokanadyjski. Wiąże się to przede wszystkim ze wspomnianymi wyżej podziałami wewnątrz samej grupy, które mocno warunkowane są z regionem, z którego Portugalczycy emigrowali. Pojawiły się też pierwsze gazety w języku portugalskim. Na początku były to kilkustronicowe parafialne biuletyny. Pierwsza gazeta „O Luso-Canadiano”, wychodziła w Montrealu od roku 1959 (do 1971), w Toronto w 1963 powstała „Correio Portugues” (The Portuguese Mail), która wychodzi do dziś pod zmienioną nazwą „Correiro da Manha” (The Portuguese Canadian Newspaper). Było także wiele innych tytułów, jednak przez pierwsze dziesięciolecia prasa portugalskojęzyczna w Kanadzie nie miała wielu odbiorców, gdyż duża część pokolenia imigrantów miała spore problemy z czytaniem. W latach 70. XX w., w znacznej mierze dzięki dotacjom z budżetu polityki pluralizmu kulturowego, w kanadyjskich publicznych rozgłośniach pojawiły się pierwsze portugalskojęzyczne audycje radiowe i telewizyjne, i te były bardzo popularne. Dziś dominują oczywiście media elektroniczne, wśród których znajdują się na przykład miesięczniki „Voz Lusitana” i „Lusitania Canadian Online Magazine” czy dwujęzyczny portal „Portugal Post - Portugal News”.

W 2007 roku, pół wieku od założenia pierwszych etnicznych instytucji, portugalska grupa etniczna w Kanadzie posiadała 34 kościoły, 32 szkoły, przede wszystkim weekendowe, 211 organizacji i klubów oraz ponad 6 tysięcy mniejszych i większych biznesów etnicznych ${ }^{40}$. Na przełomie XX i XXI wieku diaspora portugalska w większości nie mieszkała już w zwartych sąsiedztwach. Portugalczycy kupowali domy i przenosili się na obrzeża Toronto, Montrealu czy Vancouver, jednak badania przeprowadzone w 2001 roku pokazały, że grupa ta jest nadal jedną z najbardziej izolowanych grup etnicznych, bardzo słabo integrującą się ze społeczeństwem kanadyjskim i mimo zmiany miejsca zamieszkania nadal mentalnie pozostającą $\mathrm{w}$ getcie etnicznym ${ }^{41}$.

Przyczyn takiego stanu rzeczy można doszukiwać się także w nadal niskim poziomie wykształcenia portugalskiej diaspory. Kolejne pokolenia urodzone w Kanadzie uczyły się w kanadyjskich szkołach, ale i w ich przypadku edukacja nie jest preferowaną przez większość drogą rozwoju. Wielu młodych rezygnowało z nieobowiązkowej nauki i szło do pracy, aby pomóc finansowo rodzinie. Szczególnie ważne dla portugalskiej grupy było posiadanie własnego domu i między innymi z tego powodu, aby rodzina mogła go jak najszybciej kupić, wybierano pracę a nie edukację. ${ }^{42}$ Dlatego też, mimo że kolejne pokolenia legitymują się wyższym stopniem edukacji niż ich rodzice, to jednak w stosunku do innych grup etnicznych

40 Teixeira, da Rosa, 2009 s. 7, tab. 1.2.

${ }^{41}$ Qadeer, M., Kumar, S., 2006, Ethnic Enclaves and Social Cohesion, „Canadian Journal of Urban Research", 15, s. 1-17.

${ }^{42}$ Badania pokazały, że tak uważa większość, niemal 90\%, osób pochodzenia portugalskiego. Teixeira, C., Murdie R.C., 2009, On the Move. The Portuguese in Toronto, in: Teixeitra, da Rosa, 2009, s. 196. 
grupa portugalska wypada bardzo słabo ${ }^{43}$. Przykładowo, w 2006 roku niemal 25\% populacji dorosłych mieszkańców Toronto miało zaliczone jakiekolwiek kursy uniwersyteckie, a wśród osób pochodzenia portugalskiego było to jedynie 5\%. Co przekładało się oczywiście na ich niski status zawodowy ${ }^{44}$. Z kolei statystyki montrealskie pokazują, że w 2001 roku 48,5\% osób portugalskiego pochodzenia mieszkających w Montrealu miało wykształcenie poniżej średniego ${ }^{45}$. Natomiast w obu metropoliach Portugalczycy legitymują się najwyższym odsetkiem wśród właścicieli domów. W 2006 roku 63\% mieszkańców Toronto było właścicielami domów, wśród osób pochodzenia portugalskiego było to $88,5 \%$, a w Montrealu $76 \%{ }^{46}$.

\section{Ontario, Quebec, Kolumbia Brytyjska - tu mieszka najwięcej Portugalczyków}

Portugalczycy, jak niemal wszystkie inne grupy etniczne migrujące w ciągu ostatniego półwiecza do Kanady, preferowali osiedlanie się w prowincji Ontario, a w szczególności w Toronto. Już w II połowie lat 50. XX w., po niełatwych doświadczeniach w pracy na farmach, większość imigrantów z grupy „pionierskiej” zdecydowała się na przenosiny do miast. Wówczas przede wszystkim było to Toronto, rzadziej Montreal.

Kensington Market, leżący w samym centrum Toronto, był wówczas dzielnicą, gdzie swoje emigracyjne życie zaczynali imigranci z wielu krajów. Pierwsi Portugalczycy także zamieszkali w tym rejonie, zapoczątkowując wiele dekad portugalskiego osadnictwa w tej części Toronto. W miarę upływu lat Kensington Market $\mathrm{z}$ sąsiadującym Alexandra Park stały się portugalską dzielnicą, tzw. Little Portugal. W II połowie lat $50 . \mathrm{XX}$ w. imigranci luzofońscy sąsiadowali bezpośrednio z grupą węgierskich Żydów, którzy dotarli do Kanady po rewolucji 1956 roku. Powstałe wokół Augusta Avenue sklepy, restauracje i firmy żydowskie szybko obrastały także w portugalski handel i usługi. W ciągu kilku lat tzw. rynek żydowski zamienił się w portugalski, a Augusta Ave. zyskała nazwę rua dos Portugueses. Okolicę nazywano Portugal Village lub Little Portugal ${ }^{47}$. Portugalczycy zamienili tę tanią, mało elegancką dzielnicę w kolorową enklawę. Domy, sklepy, restauracje malowali na jasne kolory, meble ogrodowe i kuchenne na niebiesko, a ściany domów ozdabiali

${ }^{43}$ Statistics Canada 2001; da Rosa, V., Teixeira, C., 2009, The Portuguese Community in Quebec, w: Teixeira, da Rosa 2009, s. 210-211.

${ }^{44}$ Teixeira, Murdie, 2009 s. 204-206.

45 da Rosa, Teixeira, 2009, s. 210.

${ }^{46}$ Ibidem s. 210; Teixeira, Murdie, 2009 s. 205; Teixeira, C., 2006, Étude comparée de la suburbanisation des nouveaux propriétaires portugais à Montréal et Toronto, „Espace populations sociétés”, no.1, s. 121-135.

47 Teixeira, Murdie, 2009, s. 192; Marques, Domingos, Medeiros, João, 1984, Portuguese Immigrants in Toronto, „Polyphony” Summer, s. 154. 
przysłanymi z kraju azulejos. Przed domami uprawiali ogródki z obowiązkową kapustą na caldo verde, kwiatkami, a nawet winną latoroślą, między którymi zazwyczaj stała figura Matki Boskiej Fatimskiej, św. Antoniego lub innego świętego czczonego w minha terra. Zamiłowanie do uprawiania przydomowych ogródków było, według badaczy, echem tęsknot do życia, jakie wiedli w ojczyźnie. Na przełomie lat 60. i 70. XX w. Portugalczycy stanowili ponad 75\% mieszkańców torontońskiego Portugal Village $e^{48}$.

Życie portugalskiej diaspory w Toronto koncentrowało się wokół Kensington Market mniej więcej do końca lat 70. XX wieku. Przez ponad dwie dekady zbiorowość ta urosła do niemal pięćdziesięciu tysięcy osób. Ciągle przybywali nowi, ale i rosły pokolenia urodzone już w Kanadzie, Little Portugal stawała się coraz bardziej ciasna. Od końca lat 70. XX w., wzorem innych grup, diaspora portugalska zaczęła przenosić się, tzw. imigracyjnym korytarzem, w kierunku północno-zachodnim, do dzielnic, które właśnie opuszczała grupa włoska. Bardziej zasobne rodziny wybierały przedmieścia Toronto, w tym głownie Missisagua. W 1981 roku osoby czysto portugalskiego pochodzenia stanowiły około 45\% (około 52 tys.) mieszkańców Portugal Village, dziesięć lat później 37\% (43 tys.), a w 2006 roku niespełna 25\% (24 tys.). Mimo konsekwentnie postępującego rozpraszania się portugalskiej grupy etnicznej w Merto Toronto, centrum jej etnicznego życia pozostały nadal okolice Kensington Market ${ }^{49}$. Ontario, w szczególności Toronto, to miejsca, gdzie w 2007 roku pracowało ponad 5 tysięcy mniejszych lub większych firm założonych przez luzofońskich imigrantów, działało ponad sto portugalskich klubów i organizacji oraz 20 portugalskojęzycznych szkół etnicznych, a posługę religijną czyniły 23 portugalskie kościoły ${ }^{50}$.

Wydawałoby się, że Quebec będzie prowincją, gdzie w latach 50. XX w. portugalscy imigranci będą chętnie się osiedlać. Ich osadnictwu mógłby sprzyjać choćby rolniczy charakter tej prowincji czy quebecki katolicyzm, język nie byłby przeszkodą, bo ci imigranci nie znali ani francuskiego ani angielskiego. Jednak przez ponad pół wieku w zdecydowanej większości jechali dalej, do Ontario. Quebec był drugą w kolejności prowincją, w której się osiedlali, w 2011 roku mieszkało ich tu sześć razy mniej niż w Ontario. Dziś wśród portugalskiej diaspory w Quebecu imigranci stanowią ponad 40\%, wśród nich przeważają ci (60\%), którzy przyjechali przed 1981 rokiem $^{51}$.

48 Teixeira, Murdie, 2009, s. 194-195, 201.

${ }^{49}$ Ibidem, p. 2000. W 2006 roku Kensington Market został uznany za historyczne miejsce Kanady, w uznaniu wyjątkowej roli, jaką pełnił dla wielu grup etnicznych zaczynających tu swoje kanadyjskie życie. Ibidem, s. 195.

${ }_{50}$ Teixeira, C., da Rosa, V., 2009, A Historical and Geographical Perspective, w: Teixeira, da Rosa, 2009, s. 7, tab. 1.2.

${ }^{51} \mathrm{http} / /$ www.quebecinterculturel.gouv.qc.ca/publications/fr/diversite-ethnoculturelle/com-portugaise2011.pdf, s. 3 (dostęp: 2018-03-25). 
Ze względu na skomplikowane relacje między grupami etnicznymi a dominującymi w prowincji Quebecois, jedynym miejscem, gdzie imigranci osiedlali się w większej liczbie, był Montreal52. W 2011 roku w metropolii montrealskiej żyło ponad 85\% portugalskiej grupy etnicznej mieszkającej w Quebecu, czyli około 34 tys. osób ${ }^{53}$. Te kilkanaście pozostałych procent rozproszone jest w kilku mniejszych miastach Quebecu. Większa zbiorowość mieszka w Gatineau-Hull, mieście sąsiadującym przez rzekę Ottawę ze stolicą Kanady oraz w Laval. W pierwszym z tych miast w 2006 roku mieszkało około 3,5 tys. osób portugalskiego pochodzenia, z których 2,8 tys. deklarowało język portugalski jako ojczysty. Niemal 95\% tej grupy pochodzi z Azorów, przede wszystkim z parafii Maia na wyspie Sao Miguel. Mężczyźni pracują głównie w budownictwie, wcześniej przy wycince lasów, a kobiety w handlu i jako sprzątaczki. Życie etniczne grupy koncentruje się wokó Centro Comunitário Português Amigos Unidos ${ }^{54}$. Z kolei do Laval, podmontrealskiego miasta (leży na Wyspie Jezusowej, Ile Jesus), dziś należącego do metropolii Montreal, od przełomu lat 70. i $80 \mathrm{XX}$ w. przenosili się Portugalczycy z centrum Montrealu w poszukiwaniu lepszego, własnego domu. W 1971 roku mieszkało tam niewiele ponad 600 osób pochodzących z Portugalii, w 2001 roku - ponad 6 tys., a w 2011 - około 8 tys. Tu także dominują przybysze z Azorów. Nie ma w tym mieście czysto portugalskich sąsiedztw, grupa jest dość rozproszona, choć są ulice przy których można znaleźć kilka czy kilkanaście portugalskich domów. Centrum życia grupy portugalskiej w Laval skupia się w parafii Matki Boskiej Fatimskiej. Warto zaznaczyć, że wiele rodzin, które osiedliły się w Laval, przybyło do Kanady z Brazylii, gdzie wcześniej wyemigrowały ${ }^{55}$.

W Montrealu portugalska grupa etniczna jest obecna od połowy lat 50. XX wieku. Pierwsi imigranci, z grupy pionierskiej, po najczęściej mało udanych okresach pracy na quebeckiej wsi, szukali pracy w dużym mieście. Niektórzy z nich zostali w Montrealu. Tu Portugalczycy zasiedlali tradycyjnie etniczne dzielnice leżące w centrum miasta, te gdzie wcześniej osiedlali się europejscy przybysze: Polacy, Żydzi, Włosi, Grecy czy inni. Wprawdzie nigdy w Montrealu nie powstała tak okazała portugalska dzielnica jak w Toronto, ale kwartały St-Louis i Mile-End były tu centrum portugalskiej zbiorowości. Na początku lat 70. XX w., wraz z Grekami, stanowili ponad $40 \%$ mieszkańców St-Louis ${ }^{56}$. Także tu dzielnice te „oswajali” w sobie właściwy sposób. „Portugalczycy pojawiając się precyzyjnie monopolizowali przestrzeń. Sklepy, domy, instytucje - pokazywały ich obecność. Kolorowe fasady,

${ }^{52}$ Kijewska-Trembecka, M., 2008, Quebec i Quebecois. Ideologie dążeń niepodległościowych. Kraków: WUJ, s. 75-92.

${ }^{53}$ http://www.quebecinterculturel.gouv.qc.ca/publications/fr/diversite-ethnoculturelle/com-portugaise2011.pdf (dostęp: 2018-03-23).

\footnotetext{
${ }^{54}$ Alpalhao, da Rosa, 1980, s. 77-78; Teixeira, da Rosa, 2009, s. 217.

55 Alpalhao, da Rosa, 1980, s. 78-79; Teixeira, da Rosa, 2009, s. 217

${ }_{56}$ Alpalhao, da Rosa, 1980, s. 75
} 
duże afisze w języku portugalskim, restauracje, bary - oni tu są"57. Już w 1956 roku $\mathrm{w}$ Montrealu powstała pierwsza w Kanadzie portugalska organizacja etniczna the Portuguese Association of Canada, Associação Portuguesa Do Canadá. Bardzo szybko portugalska wspólnota w Montrealu założyła inne stowarzyszenia i instytucje: edukacyjne, religijne, samopomocowe, zawodowe czy grupujące portugalskich, zazwyczaj drobnych, przedsiębiorców. Grupa szybko zbudowała tu potrzebną jej kompletność instytucjonalną. Na początku XXI wieku w Quebecu, w tym przede wszystkim w Montrealu, działało ponad siedemset portugalskich mniejszych i większych firm komercyjnych, ponad czterdzieści klubów i stowarzyszeń; pięć szkół etnicznych i cztery kościoły ${ }^{58}$. W 1975 roku grupa portugalska w Montrealu otrzymała Nagrodę Architektów Quebeckich w uznaniu jej wkładu w urozmaicenie architektury dzielnicy przez nią zamieszkałej, a burmistrz Montrealu Jean Drapeau nadał nazwę Park Portugalski jednemu z zielonych placów w kwartale St. Louis.

Trzecią prowincją, gdzie osiedliła się znacząca liczba portugalskich imigrantów, była Kolumbia Brytyjska. Także tu Portugalczycy preferowali miasta, w szczególności Vancouver, gdzie łatwiej było o pracę i wsparcie rodaków. W 2007 roku w mniejszych i większych miastach prowincji mieszkało ponad 75\% osób portugalskiego pochodzenia, w tym w samym Vancouver ponad $60 \%{ }^{59}$. W porównaniu do Ontario na zachód Kanady docierało niewielu luzofońskich przybyszów, nie stworzyli dużych zwartych miejskich sąsiedztw, choć w Vancouver i kilku innych miastach Kolumbii Brytyjskiej istnieją enklawy, gdzie obecność Portugalczyków jest bardziej widoczna. Portugalskie osadnictwo w tej prowincji ma jednak swój niepowtarzalny gdzie indziej wymiar. Kolumbia Brytyjska to prowincja o znakomitych walorach rolniczych i tu, jak nigdzie indziej w Kanadzie, część imigrantów przede wszystkim z kontynentalnej Portugalii związała się z sadownictwem. Można powiedzieć, że jedynie tu, kanadyjski program sprowadzania w latach 50. XX w. z Portugalii imigrantów do pracy w rolnictwie został zrealizowany. W Toronto czy Montrealu Portugalczycy zakładali sklepy, punkty usługowe, bary, tu za oszczędzone i pożyczone pieniądze kupowali sady, szczególnie w bardzo żyznej Okanagan Valley, w okolicach miejscowości: Osoyoos, Oliver, Penticton czy Kelowna ${ }^{60}$. Pionierzy, około 30 osób, przyjechali w 1955 roku i pracowali jako robotnicy rolni w sadach Okanagan Valley. Pierwszym Portugalczykiem, który kupił sad, w 1959 roku, był Joe Fernandes, jeden z grupy pionierów. Rodzina, żona i siedmioro dzieci, dołączyli do niego w 1960 roku i przez kilka lat sami pracowali w siedmioakrowym, czyli

${ }^{57}$ Lavigne, G., 1987, Les ethniques et la ville: Laventure urbaine des immigrants portugais a Montreal, Montreal: Le Preambule, s. 20.

${ }^{58}$ Informacje na podstawie danych Konsulatu Portugalii w Montrealu. Teixeira, da Rosa, 2009, s. 7.

${ }^{59} \mathrm{http}: / /$ www12.statcan.gc.ca/nhs-enm/2011 (dostęp: 2018-02-15).

${ }_{60}$ Koroscil, P.M., 2000, British Columbia: settlement history, Vancouver: Simon Fraser University, s. 155. 
niespełna trzy hektarowym sadzie. W ciągu kilku dziesięcioleci farma ogrodnicza Joe Fernandes, Fernandes Fruit Stand, rozrosła się i stała się jednym z najlepiej rozpoznawalnych "portugalskich miejsc” nie tylko w okolicach Osoyoos. Fernandes Fruit Stand wyrosła na dużą firmę sadowniczo-handlową znaną niemal w całej Kanadzie. Uprawiano tu wiele gatunków drzew owocowych, później także warzywa. Była to jedyna w Kandzie farma, gdzie rosły banany. Działała do 1993 roku, do śmierci założyciela, rok później rodzina ją sprzedała ${ }^{61}$.

Największy rozkwit portugalskich sadów w Kolumbii Brytyjskiej to lata 70 . i 80. XX wieku. W połowie lat 80. XX w. w okolicach Osoyoos ponad $220(44 \%)$ farm sadowniczych należało do Portugalczyków, a wokół Oliver aż 440 (25\%). Ich właścicielami było przede wszystkim pokolenie imigrantów. Ich dzieci preferują pracę w mieście i po odejściu rodziców najczęściej sprzedają ziemię. W 2005 roku w portugalskich rękach było jedynie 35 farm w rejonie Osoyoos i tylko $28 \mathrm{w}$ rejonie Oliver. Najczęściej przechodzą one w ręce imigrantów z Indii i Azji Południowej ${ }^{62}$. Jednak ci z grupy portugalskiej, którzy nadal zajmują się sadownictwem w Okanagan Valley, nierzadko odnoszą sukcesy w swoim biznesie. Przykładem może być Jack Machial. Do Okanagan przyjechał w 1964 roku ze środkowej Portugalii i jako 12-letni chłopiec pracował tu przy zbiorze czereśni. W 2005 roku jego farma sadownicza otrzymała prestiżową Golden Apple Award za wyhodowanie wspaniałych owoców i doskonale prowadzenie farmy ${ }^{63}$.

Ciekawy jest jeszcze inny wymiar życia portugalskich imigrantów w Kolumbii Brytyjskiej. W przeciwieństwie do osiadłych we wschodnich prowincjach, tu, na zachodzie, Portugalczycy nie starali się o tworzenie etnicznych sąsiedztw, nie kupowali farm blisko siebie, a raczej tam, gdzie była lepsza oferta. Starali się zintegrować ze wspólnotą szerszą i niejako podporządkować etniczną i kulturową lojalność potrzebom lokalnej zbiorowości, która ich przyjęła. Choć oczywiście utrzymywali bliskie kontakty między sobą ${ }^{64}$.

\section{Podsumowanie}

Można powiedzieć, że portugalska grupa etniczna, mimo swojego europejskiego pochodzenia, jest w Kanadzie grupą młodą, z bardzo krótką kanadyjską historią. Emigracja Portugalczyków do Kanady zamknęła się de facto w II połowie $\mathrm{XX}$ wieku, w ostatnich dwóch dziesięcioleciach jest minimalna. W większości pochodzi z Azorów i jest intencjonalnie stała, większość Azorczyków nie bierze pod

${ }^{61}$ Teixeira, C. 2009, The Portuguese in Btitish Columbia, s. 232-233.

62 Ibidem, s. 233; Koroscil, 2000, s. 161.

${ }^{63}$ Teixeira, 2009, s. 249.

${ }^{64}$ Munzer, R.P., 1981, Immigration, Familialism and In-group Competition: A Study of Portuguese in the Southern Okanagan, „Canadian Ethnic Studies” no. 13, s. 98-11. 
uwagę powrotu. W portugalskiej grupie nadal dominuje pokolenie imigrantów, co sprawia, że wiele problemów z Europy żyje swoim życiem także na emigracji. Tu podstawową kwestią jest brak wewnętrznej jedności wśród diaspory portugalskiej. Ze względu na historyczne podziały Portugalczycy czują się związani bardziej z ojczyzną prywatną, minha terra niż ideologiczną. Tak jak w Europie poczucie ich narodowej solidarności jest rozłożone na trzy części, między Azorami, Maderą i Portugalią kontynentalną, tak na emigracji podział ten jest jeszcze mocniejszy. Tu spotykają się dawni kolonizatorzy i kolonizowani, i do dziś niezwykle trudno jest przezwyciężyć wzajemną niechęć. Jednak bez względu na to, z jakiej części Portugalii przyjechali, w Kanadzie należą do najsłabiej wykształconych i przygotowanych zawodowo grup o rodowodzie europejskim. Kolejne, już urodzone w Kanadzie, pokolenia w większości także nie poświęcają na naukę zbyt wielu lat i bardzo szybko idą do pracy. Szansy na wyjście części grupy ze schematu powielania drogi życiowej rodziców można upatrywać w etnicznej egzogamii, rosnącej wśród kolejnych pokoleń Portugalczyków w Kanadzie. Niewątpliwie grupa ta, choć niezbyt szybko, zmienia, podnosi, swoją pozycję wśród kanadyjskich grup etnicznych, szczególnie w odniesieniu do tzw. nowych grup, zwanych visible minorities. Przez pół wieku nadrzędnym celem imigrantów luzofońskich w Kanadzie było posiadanie własnego domu. Dom to nadal realizacja portugalskiego snu w tym kraju.

\section{Bibliografia}

Alpalhao, J.A., da Rosa, V. (1980), A Minority in a Changing Society. The Portuguese Communities of Quebec, Ottawa: University of Ottawa Press.

Armando Oliveira, M. (2009), Azorean Diaspora and Cultural Retention in Montreal and Toronto, w: Teixeria, da Rosa, 2009, 91-108.

Blade, Klaus J., Emmer, Peter, C., Lucassen, Leo, Oltmer, Jochen (2011), The Encyclopedia of Migration and Minorities in Europe. From the $17^{\text {th }}$ Century to the Present, Cambridge: Cambridge University Press.

Boyko, J. (1998), Last Steps to Freedom: The Evoluation of Canadian Racism, Toronto: J. Gordon Shillingford.

Breton, R. (1964), Institutional Completeness of Ethnic Communities and the Personal Relations of Immigrants, „American Journal of Sociology”, vol. LXX, September, no. 2, 193-205.

Burnet, J., Palmer, H. (1988), Coming Canadians. An Introduction to a History of Canada's Peoples, Toronto: McClelland and Steward.

da Rosa, V., Teixeira C. (2000), The Portuguese in Canada: from the sea to the city, Toronto: University of Toronto Press.

da Rosa, V., Teixeira C. (2009), The Portuguese Community in Quebec, w: Teixeira C., da Rosa V. (eds.), The Portuguese in Canada. Diasporic Challenges and Adjustment, Toronto: University of Toronto Press, 209-225.

de Oliveira Marques, Antonio H. (1987), Historia Portugalii, tom I i t. II, Warszawa: PWN.

Doel, P.A., Andrieux, J.-P., Collins, P. (2009), Newfoundland and the White Fleet, w: Teixeira C., da Rosa V. (eds.), The Portuguese in Canada. Diasporic Challenges and Adjustment, Toronto: University of Toronto Press, 44-80. 
Harney, R.F. (1990), „Portygees and Other Caucasians”. Portuguese migrants and the racialism of the English-speaking world, in: Higgs, David, (ed.), Portuguese Migration in Global Perspective, Toronto: The Multicultural History Society of Ontario, 113-135.

Hermano Saraiva, J. (2000), Krótka historia Portugalii, Kraków: Universitas.

Higgs, D. (1982), The Portuguese in Canada, Ottawa: The Canadian Historical Association.

Higgs, D. (1990), (ed.), Portuguese Migration in Global Perspective, Toronto: The Multicultural History Society of Ontario.

Kijewska-Trembecka M. (1994), Kanada - naród czy wspólnota polityczna. Analiza kanadyjskich procesów integracyjnych, Kraków: Wydawnictwo Uniwersytetu Jagiellońskiego.

Kijewska-Trembecka, M. (2008), Montrealscy Żydzi: od dyskryminacji do sukcesu, w: Szmeja M. (red.), Etniczność - o przemianach społeczeństw narodowych, Kraków: Nomos, 101-114.

Kijewska-Trembecka, M. (2008), Quebec i Quebecois. Ideologie dążeń niepodległościowych, Kraków: Wydawnictwo Uniwersytetu Jagiellońskiego.

Kijewska-Trembecka, M. (2018), Od wielkich odkryć po White Fleet. Diaspora portugalska w świecie i przedemigracyjne kontakty Portugalczyków z Kanadą, „Studia Migracyjne Przegląd Polonijny" 2, 241-257.

Kijewska-Trembecka, M. (red.), (2013), Kanada na przełomie XX i XXI wieku. Polityka, społeczeństwo, edukacja, Kraków: Księgarnia Akademicka.

Koroscil, P.M. (2000), British Columbia: settlement history, Vancouver: Simon Fraser University.

Lavigne, G. (1987), Les ethniques et la ville: L'aventure urbaine des immigrants portugais a Montreal, Montreal: Le Preambule.

Maciel, C. (2013), Portuguese retornados from the colonies in Portugal since the 1970s, in: Blade, K.J., Emmer, P.C., Lucassen, L., Oltmer, J. (eds.), The Encyclopedia of Migration and Minorities in Europe. From the $17^{\text {th }}$ Century to the Present, Cambridge: Cambridge University Press, 623-625.

Marques, D., Medeiros, J. (1980), Portuguese Immigrants. 25 Years in Canada, Toronto: Marquis Printers.

Marques, D., Medeiros, J. (1984), Portuguese Immigrants in Toronto, „Polyphony” Summer, 154-158.

Miranda, S.M. (2009), Portuguese Women's Activism in Toronto's Building Cleaning Industry, in: Teixeira C., da Rosa V. (eds.), The Portuguese in Canada. Diasporic Challenges and Adjustment, Toronto: University of Toronto Press, 109-135.

Munzer, R.P. (1981), Immigration, Familialism and In-group Competition: A Study of Portuguese in the Southern Okanagan, „Canadian Ethnic Studies” no. 13, 98-11.

Ossowski, S. (1984), Analiza socjologiczna pojęcia ojczyzny, w: O ojczyźnie i narodzie, Warszawa: PWN.

Qadeer, M., Kumar, S. (2006), Ethnic Enclaves and Social Cohesion, „Canadian Journal of Urban Research", 15, 1-17.

Rayburn, A. (1994), Naming Canada. Stories about Place Names from Canadian Geographic, Toronto: University of Toronto Press.

Rocha-Trindade M.B. (2009), The Portuguese Diaspora, in: Teixeira C., da Rosa V. (eds.), The Portuguese in Canada. Diasporic Challenges and Adjustment, Toronto: University of Toronto Press, 18-41.

Teixeira, C. (2006), Étude comparée de la suburbanisation des nouveaux propriétaires portugais à Montréal et Toronto, „Espace populations sociétés”, 1, 121-135.

Teixeira C., da Rosa V.M.P. (2009), The Portuguese in Canada. Diasporic Challenges and Adjustment, Toronto: University of Toronto Press. 
Teixeira C., da Rosa V.M.P. (2009), A Historical and Geographical Perspective, in: Teixeira C., da Rosa V. (eds.), The Portuguese in Canada. Diasporic Challenges and Adjustment, Toronto: University of Toronto Press, 3-17.

Teixeira, C., Murdie R.A. (2009), On the Move. The Portuguese in Toronto, in: Teixeira C., da Rosa V. (eds.), The Portuguese in Canada. Diasporic Challenges and Adjustment, Toronto: University of Toronto Press, 191-208.

The Canadian Family Tree. Canada's People, 1979, Don Mills: Multiculturalism Directorate.

Walaszek, A. (2007), Migracje Europejczyków 1650-1914, Kraków: Wydawnictwo Uniwersytetu Jagiellońskiego.

Walaszek, A. (2013), Dwie europejskie peryferie: porównanie migracji portugalskich i polskich od XVI wieku do wielkiej wojny, „Studia Migracyjne - Przegląd Polonijny” nr 2, 16-50.

\section{Strony internetowe:}

http://observatorioemigracao.pt/Canada

http://www.statcan.gc.ca

http://www.statistiques.public.lu

http://www12.statcan.gc.ca

https://www.ine.pt

https://www.iscte-iul.pt

https://www.portugal.gov.pt

https://www.yelp.ca

http://www12.statcan.gc.ca

http://www.whitepinepictures.com/seeds/ii/22/history3.html;

www.quebecinterculturel.gouv.qc.ca/publications/fr/diversite-ethnoculturelle/com-portugaise2011.pdf

www. statcan.ca/historical_profiles 